\title{
Evaluasi Implementasi Program Keluarga Harapan di Indonesia: Quick Evaluation Analysis
}

\author{
Evaluation the Implementation of Famly of Hope Program in Indonesian: \\ Quick Evaluation Analysis
}

\author{
${ }^{1}$ Anugerah Yuka Asmara, ${ }^{\square}$ Irwantoro, ${ }^{3}$ Mochammad Rozikin, ${ }^{2}$ Adibah Sayyidati \\ ${ }^{1}$ Lembaga Ilmu Pengetahuan Indonesia \\ ${ }^{2}$ Badan Penelitian dan Pengembangan Provinsi Jawa Timur, Indonesia \\ ${ }^{3}$ Fakultas Ilmu Administrasi Universitas Brawijaya Malang, Indonesia
}

DOI: 10.32781/cakrawala.v15i1.367

\begin{tabular}{l}
\hline ARTICLE INFO \\
Evaluasi, \\
Implementasi, \\
Program Keluarga Harapan, \\
Kesejahteraan.
\end{tabular}

Article History:

Received : 10 Maret 2021

Accepted : 16 Juni 2021

Publish : 17 Juni 2021

\begin{abstract}
Abstrak:
Tujuan studi ini adalah menganalisis peran para pendamping terkait penggunaan dana Program Keluarga Harapan dan menganalisis pola pengelolaan dana Program Keluarga Harapan di level lembaga akibat adanya praktik multiple benefeciaries. Penelitian ini menggunakan pendekatan kualitatif deskriptif dengan menekankan pada analisis fenomena di lapangan. Hasil dan kesimpulan yang diperoleh dari penelitian ini adalah (1)Kompetensi dan kapabilitas pendamping masih belum optimal oleh karena itu diperlukan pembekalan bagi tim pendamping baik pendidikan dan pelatihan, workshop, sosialisasi atau bentuk peningkatan kompetensi; (2) Pemutakhiran data keluarga penerima bantuan masih menjadi pekerjaan rumah bagi Badan Pusat Statistik dan Kementerian Sosial untuk evaluasi pemutakhiran data sebaiknya dapat dilakukan secara online yang langsung dapat dilakukan oleh tim pendamping di lapangan dan terhubung dengan dinas sosial kabupaten/kota provinsi, Badan Pusat Statistik, dan Kementerian Sosial; (3) Diperlukan integrasi Program Keluarga Harapan dengan program lain yang menjadi single beneficiarymembutuhkan koordinasi antar lintas sektor antara lembaga pemerintah sehingga diperlukan penguatan regulasi dengan peraturan presidenbahkan peraturan pemerintah untuk memperkuat kewenangan Kementerian Sosial untuk menjalankan program komplementer Program Keluarga Harapan; (4) Melakukan penyusunan program bersama kementerian/lembaga dengan dasar Rencana Pembangunan Jangka Menengah di bidang jaminan sosial dan perlindungan keluarga miskin dengan berbagai skema bantuan.
\end{abstract}

\section{Abstract:}

The purpose of the study analyzing those accompanied related to the use of the role of the family of hope and analyzing management pattern of the family of hope at benefeciaries multiple institutions as a result of these practices. This study adopted qualitative approaches descriptive by stressing analysis the phenomenon in the field. The results and conclusions obtained from this study is (1) Competence and capability counterparts is not yet optimal therefore required a briefing for the advocacy team good education and training, the workshop, the socialization or form of increased competence; (2) Updating the data of beneficiary families is still a homework for the Central Bureau of Statistics and the Ministry of Social Affairs for the evaluation of updating data, it should be done online which can be directly carried out by the counterpart team in the field and connected with the district/ city provincial social services, the Central Bureau of Statistics, and the Ministry of Social Affairs; (3) Integration of the Family Hope Program with other programs that become single beneficiaries requires coordination between sectors between government agencies so that regulations are needed to strengthen regulations with presidential regulations and even government regulations to strengthen the authority of the Ministry of Social Affairs to carry out the complementary program of the Family Hope Program; (4) Conducting joint ministry / agency programming based on the Medium-Term Development Plan in the field of social security and protection of poor families with various assistance schemes.

\footnotetext{
Corresponding author:

Address : : Jl. Gayung Kb. Sari No.56, Gayungan, Kota SBY, Jawa Timur 60235

Email : irwanlitbangjatim@yahoo.co.id
} 


\section{PENDAHULUAN}

Program Keluarga Harapan (PKH) menjadi salah satu kebijakan pemerintah yang diimplementasikan sejak tahun 2007 oleh Kementerian Sosial Republik Indonesia. Perkembangannya, PKH menjadi isu kebijakan populer nasional saat ini karena program ini langsung menyentuh kelompok sasaran (target groups) masyarakat kelas ekonomi bawah dengan memberikan bantuan tunai bersyarat kepada rumah tangga sangat miskin (RTSM) dengan persyaratan khusus yaitu ibu hamil, menyusui, dan mempunyai anak usia sekolah serta mereka mematuhi ketentuan dan persyaratan perihal upaya peningkatan kualitas sumber daya manusia (SDM) di bidang pendidikan dan kesehatan (Kementerian Sosial, 2013).

Masyarakat miskin dan isu gender juga menjadi perhatian dari kebijakan $\mathrm{PKH}$ ini. Tentu hal ini tidak mudah dijalankan mengingat dinamika sosial serta karakter kelompok masyarakat di tiap daerah yang berbeda. Ditambah lagi dengan kondisi geografis dan juga keterbatasan sumber daya dalam pelaksanaan kebijakan menjadi tantangan dari implementasi kebijakan ini. Tantangan terberat dari kebijakan $\mathrm{PKH}$ ialah sejauh mana kebijakan ini dapat diimplementasikan secara tepat kepada kelompok sasaran.

PKH bertujuan untuk mengurangi tingkat kemiskinandi masyarakat, meskipun dalam praktiknya tidak ada ukuran yang terstandardisasi untuk menentukan penurunan level kemiskinan di masyarakat kecuali "ukuran angka" yang menyatakan bahwa jumlah masyarakat yang menerima PKH sudah berkurang (Utomo, 2014; Virogretta, 2015). Tentu ukuran tersebut bukanlah ukuran mutlak untuk menilai apakah kebijakan PKH dianggap berhasil dalam menurunkan tingkat kemiskinan masyarakat di wilayah tersebut. Ada ukuran dan faktor lain mengapa angka penerima masyarakat penerima $\mathrm{PKH}$ turun di wilayah tersebut, misalnya individu tersebut lulus sekolah, pindah daerah, atau meninggal dunia.

Program yang telah berjalan selama sepuluh tahun ini, tentunya memunculkan berbagai persoalan dan capaian yang itu telah dipelajari dan dievaluasi oleh berbagai pihak baik dari lembaga pemerintah maupun dari kalangan akademisi/peneliti. Alamin (2010), melihat kebijakan PKH dengan menitikberatkan pada pendamping yang selama ini menjadi garda terdepan dari pelaksanaan PKH. Di lapangan, pendamping ternyata menemui banyak hambatan mulai dari faktor masyarakat sendiri yang kurang pro-aktif sehingga peran pendamping harus lebih ditingkatkan tidak hanya sebagai verifikator data lapangan, melainkan harus mampu memiliki keahlian untuk berkomunikasi, memecahkan persoalan di penerima $\mathrm{PKH}$, bisa mencarikan sumber pendanaan tambahan, dan motivator bagi mereka yang berada di titik rawan kemiskinan.

Kementerian Keuangan (2015), memandang kebijakan PKH sebagai upaya membangun sistem perlindungan sosial kepada masyarakat miskin dalam rangka mempertahankan dan meningkatkan kesejahteraan sosial penduduk miskin sekaligus sebagai upaya memotong rantai kemiskinan terutama di bidang kesehatan dan pendidikan. Sejak tahun 2007, justru kelompok rumah tangga sangat miskin (RTSM) sebagai penerima bantuan ini meningkat dari 500.000 RTSM (alokasi sebesar Rp. 843.600.000.000) menjadi 3.500.000 RTSM (alokasi Rp. 6.457.162.000.000). Selain itu, adanya penggunaan uang tunai PKH oleh RTSM yang peruntukannya bukan untuk meningkatkan akses terhadap layanan pendidikan dan kesehatan perlu dievaluasi kembali oleh pemerintah.

Persoalan-persoalan di dalam implementasi kebijakan PKH sebagaimana dipaparkan di atas menunjukkan bahwa 
PKH masih menyisakan banyak pekerjaan rumah (PR) bagi pemerintah pusat dan daerah sebagai agen publik yang dekat dengan kelompok sasaran penerima CCT dari PKH. Meskipun banyak persoalan, namun PKH tergolong salah satu kebijakan populis yang diambil dan dijalankan oleh stakeholders di Indonesia. Buktinya, kebijakan PKH yang semula ditarget hanya sampai tahun 2015 ternyata sampai saat ini masih berjalan. Beberapa bentuk evaluasi kebijakan PKH perlu dilakukan agar kebijakan ini bukan untuk kepentingan politis semata atau untuk membelanjakan habis anggaran belanja negara, namun benar-benar untuk peningkatan taraf kehidupan keluarga miskin di Indonesia.

Kementerian Sosial (2016), memfokuskan penyempurnaan PKH dilakukan dalam 2 aspek besar yaitu perbaikan penentuan sasaran (targeting) dengan Social Registry Information System dan perbaikan mekanisme pelaksanaan program. Sejalan dengan hal tersebut, persoalan-persoalan implementasi PKH yang menjadi perhatian serius dalam tulisan ini dapat diklasifikasikan menjadi 2 (dua) pertanyaan yaitu:

a. Bagaimana implementasi penggunaan dana PKH apabila dikaitkan dengan peran para pendamping pada kelompok sasaran?

b. Bagaimana pola pengelolaan dana PKH secara kelembagaan ?(Saat ini PKH masih menghasilkan multiple benefeciaries/penerima manfaat lebih dari satu program).

\section{TINJAUAN PUSTAKA}

\section{Program Keluarga Harapan (PKH)}

Program Keluarga Harapan (PKH) yang dijalankan mulai Juli 2007 bertujuan untuk mengurangi angka kemiskinan rumah tangga sangat miskin (RTSM) khususnya di bidang kesehatan dan pendidikan melalui mekanisme conditional cash transfer (CCT) dengan beberapa persyaratan tertentu (Utomo, 2014; Zufri, 2014; Hanif, 2015; Hikmat, 2017). Persyaratan tertentu yang dimaksud ialah adanya anak usia sekolah baik di level sekolah dasar (SD), sekolah menengah pertama (SMP), ada anak balita, ibu hamil dan menyusui yang sulit dalam mendapatkan akses pendidikan dan kesehatan (Alamin, 2010; Nafatilona, 2011; Hanif, 2015).

Landasan hukum kebijakan PKH berdasar pada Undang-undang nomor 40 Tahun 2004 tentang Sistem Jaminan Sosial Nasional; Undang-undang nomor 13 Tahun 2011 tentang penanganan Fakir Miskin; Peraturan Presiden nomor 15 Tahun 2010 tentang Percepatan Penanggulangan Kemiskinan; Inpres nomor 3 Tahun 2010 tentang Program Pembangunan yang Berkeadilan poin lampiran ke 1 tentang Penyempurnaan Pelaksanaan Program Keluarga Harapan; Inpres nomor 1 Tahun 2013 tentang Pencegahan dan Pemberantasan Korupsi poin lampiran ke 46 tentang Pelaksanaan Transparansi Penyaluran Bantuan Langsung Tunai Bersyarat Bagi Keluarga Sangat Miskin (KSM) Sebagai Peserta Program Keluarga Harapan (PKH) (Kementerian Keuangan, 2015).

PKH juga ditujukan untuk 1) meningkatkan kondisi sosial ekonomi RTSM; 2) meningkatkan taraf pendidikan anakanak RTSM; 3) meningkatkan status kesehatan dan gizi ibu hamil, ibu nifas, dan anak di bawah 6 tahun dari RTSM; 4) meningkatkan akses dan kualitas pelayanan pendidikan dan kesehatan, khususnya bagi RTSM (Zufri, 2014; Kementerian Keuangan, 2015), serta 5) meningkatkan kualitas hidup penyandang disabilitas dan lansia (Hikmat, 2017).

Tujuan PKH dapat dimaknai sebagai bentuk intervensi pemerintah dalam menangani kegagalan pasar dengan adanya eksternalitas negatif yang ditimbulkan swasta, khususnya bagi masyarakat miskin yang rentan terhadap dampak 
negatif tersebut melalui peningkatan akses terhadap pelayanan pendidikan dan kesehatan. Selain itu, PKH memberikan peran lebih besar dan ruang lebih leluasa terhadap perempuan dalam mengelola keuangan rumah tangga karena memang perannya yang sentral dalam mengurus kehidupan rumah tangga, termasuk bidang pendidikan anak dan kesehatan keluarga (Hanif, 2015).

\section{Evaluasi Kebijakan}

Definisi kebijakan sangat beragam yang hal itu berkenaan dengan keputusan dan upaya yang dilakukan dari pemerintah. Kebijakan ialah pilihan yang dibuat oleh pemerintah untuk menjalankan beberapa arah tindakan (Howlett dan Ramesh dalam Maksum, 2017). Kebijakan merupakan proses dinamis, bukan sekedar sebagai suatu sistem, dan apabila perlu dapat dipaksakan berlakunya karena memang ada unsur kekuasaan pada pemerintah, sebagai pelaku dan penggerak serta pelaksana kebijakan, sehingga tercapai dan terwujud tujuan beserta keputusan-keputusan lainnya dalam kebijakan tersebut yang sesuai dengan kepentingan masyarakat (Setyodarmodjo, 2005).

Evaluasi secara umum merupakan metoderisetyangberupayamenginvesitigasi secara sistematis efektivitas intervensi di sektor sosial yang bertujuan untuk meningkatkan kondisi sosial (Davies, 2008). Evaluasi kebijakan ialah tiap aturan atau prinsip yang suatu penggunaan grup atau organisasi yang mengarahkan berbagai keputusan dan tindakannya ketika menjalankan evaluasi (Trochim, 2009). Suatu panduan menerapkan prinsip-prinsip dan metode evaluasi untuk membahas konten, implementasi atau dampak dari suatu kebijakan. Ini adalah cara kita mengembangkan sebuah pemahaman dari kebijakan yang layak dan proporsional (merit), bernilai (worth), dan bermanfaat (utility) untuk meningkatkan kondisi sosial dan ekonomi dari stakeholders yang berbeda (CDC, tanpa tahun).

Patton dkk. (2013), mengartikan evaluasi kebijakan sebagai analisis untuk menemukan masalah dalam suatu proses kebijakan dan berusaha memberikan alternatif kebijakan yang sesuai, bagaimanapun informasi menjadi kunci dalam tahap ini. Mereka selanjutnya menggunakan istilah berbeda untuk evaluasi kebijakan dan monitoring kebijakan. Menurutnya, evaluasi kebijakan bukanlah aktivitas yang hanya terjadi saat kebijakan berakhir, melainkan itu bisa dilakukan di awal kebijakan. Jadi saat kebijakan itu akan dirumuskan (ex ante) hingga kebijakan itu sedang dijalankan dan setelah dijalankan (ex post) maka evaluasi kebijakan sudah dilakukan dan menjadi proses yang berlanjut (continuum). Evaluasi kebijakan sangat penting dilakukan terkait dengan waktu terbatas dan sumber daya terbatas.

\section{Evaluasi Implementasi Kebijakan}

Evaluasi implementasi kebijakan merupakan bagian dari evaluasi kebijakan yang memiliki banyak istilah. Henry dalam Setyodarmodjo (2005) dan Nugroho (2011), menyebut implementasi kebijakan dengan evaluasi formatif. Sementara Palumbo dalam Setyodarmodjo dan Nachmias (1979) menyebut evaluasi implementasi kebijakan dengan istilah teknik evaluasi proses. Di sisi lain Hill (1993) menyebut istilah evaluasi implementasi kebijakan dengan evaluasi kebijakan post-hoc, sementara Patto dkk. (2013), menyebut dengan istilah evaluasi kebijakan ex-post yang itu bisa berarti evaluasi saat kebijakan sedang berjalan dan telah memiliki dampak maupun kebijakan yang sepenuhunya selesai dijalankan.

Paton dkk. (2013), menyatakan bahwa evaluasi kebijakan ex-post memiliki pengertian umum, melibatkan pembahasan sejauh mana tujuan-tujuan kebijakan tercapai. Hal ini memerlukan informasi kualitatif dan kuantitatif yang diperoleh 
selama monitoring kebijakan terhadap tujuan-tujuan program tersebut apakah dilanjutkan, dilanjutkan dengan modifikasi kebijakan atau dihentikkan karena tidak sesuai tujuan atau menghasilkan dampak negatif yang tidak diinginkan.

Evalusi saat kebijakan dijalankan atau evaluasi implementasi kebijakan disini disebut sebagai evaluasi formatif untuk memudahkan penulis dan membaca dalam memahami analisis selanjutnya. CDC (tanpa tahun) menekankan bahwa implementasi kebijakan ialah komponen kritikal untuk memahami derajad efektivitasnya. Evaluasi implementasi kebijakan dapat memberikan informasi penting tentang batas-batas dan fasilitatorfasilitator dari suatu implementasi dan suatu perbandingan diantara beberapa komponen atau intensitas implementasi. Evaluasi implementasi kebijakan penting bagi negara sedang berkembang, sebagaimana Makinde (2005), mengemukakan bahwa implementasi kebijakan masih sering terkendala di negara-negara sedang berkembang sehingga tujuan kebijakan sering tidak tercapai, misalnya karena faktor komunikasi, struktur birokrasi, perilaku, dan sumber daya (Gambar 1).

\section{METODE PENELITIAN}

Penelitian ini menggunakan pendekatan kualitatif deskriptif dengan menekankan pada analisis fenomena di lapangan. Menurut Sugiyono (2004) penelitian deskriptif ialah "penelitian yang dilakukan untuk mengetahui nilai variabel mandiri, baik satu variabel atau lebih (independen) tanpa membuat perbandingan, atau menghubungkan antara variabel satu dengan variabel yang lain".

Penelitian kualitatif menekankan pada penjelasan dan gambaran dari penulis untuk menganalisis fenomena yang ada dan dikaitkan dengan teori yang ada. Untuk itu, studi ini menekankan pada analisisdeskriptif terhadap suatu fenomena yang didasarkan pada landasan teori yang ada dan juga pemahaman penulis untuk menginterpretasikan data yang ada menjadi suatu pengetahuan ilmiah yang dapat dipertanggungjawabkan kebenarannya.

\section{Sumber dan Teknik Pengumpulan Data}

Sebagian besar data diperoleh melalui penelusuruan literatur (data sekunder) yang diakses dari berbagai buku, jurnal ilmiah, dokumen pemerintah, bahan kuliah, policy brief dan berbagai dokumen terkait. Selain itu, penulis menggunakan data primer dengan melakukan wawancara via telepon pada 1 (satu) orang pendamping Program Keluarga Harapan (PKH) di Kecamatan Srengat Kabupaten Blitar Provinsi Jawa Timur.

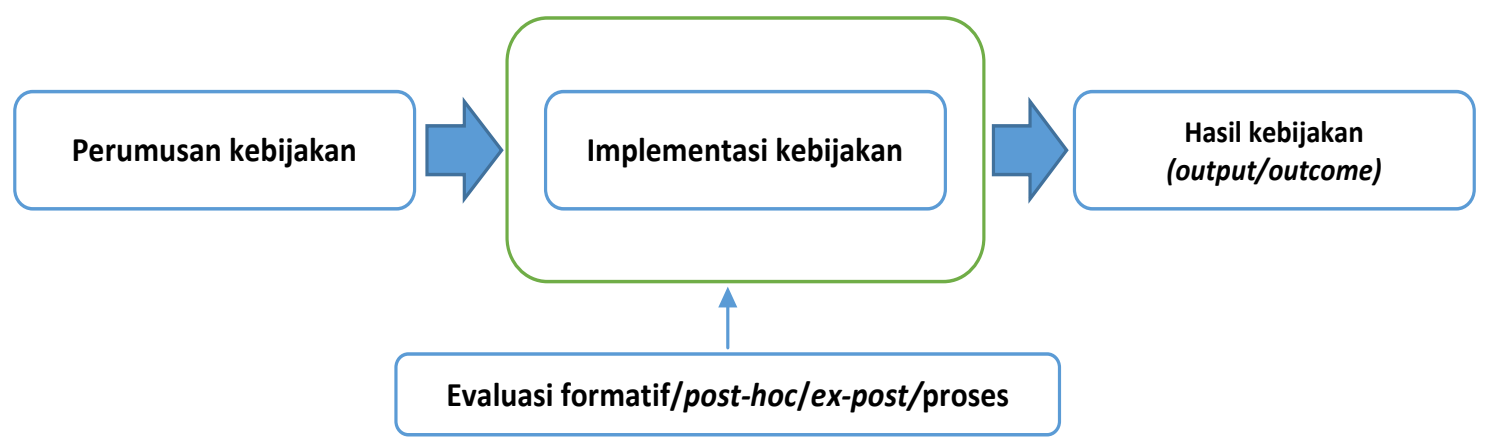

Sumber: Interpretasi penulis dari Nachmias (1979); Hill (1993); Setyodarmodjo (2005); Nugroho (2011); Patton dkk., (2013)

\section{Gambar 1}

Evaluasi Implementasi Kebijakan 


\section{Waktu dan Fokus Penelitian}

Waktu penelitian dilakukan selama 1 (satu) minggu terhitung dari tanggal 17 Oktober 2017 hingga 24 Oktober 2017. Mengingat terbatasnya sumber daya waktu, maka penelitian ini dilakukan dengan mempersempit fokus penelitian. Adapun yang menjadi fokus penelitian ialah:

a. Persoalan penggunaan dana $\mathrm{PKH}$ tidak sesuai peruntukannya khususnya untuk bidang kesehatan dan pendidikan dengan menekankan keterlibatan pendamping pada kelompok sasaran penerima bantuan PKH.

b. Secara kelembagaan, penyaluran dana PKH masih menghasilkan multiple benefeciaries atau penerima manfaat lebih dari satu program.

\section{Teknik Analisis Data}

Berdasar metode penelitian, studi ini masuk kategori penelitian evaluasi. Sugiyono (2004), menyatakan bahwa "sebagai evaluasi berarti hal ini merupakan bagian dari proses pembuatan keputusan, yaitu untuk membandingkan suatu kejadian, kegiatan, dan produk dengan standar dan program yang telah ditetapkan. Evaluasi sebagai penelitian berarti akan berfungsi untuk menjelaskan fenomena". Karena studi kualitatif, maka istilah "perbandingan" disini bukan membandingkan objek penelitian dengan objek lain serupa, namun sebagai bentuk penilaian antara capaian yang ada dengan sasaran kebijakan yang ditetapkan.

Evaluasi format ialah menilai dan menjelaskan hal apa saja fenomena atau akibat yang ditimbulkan saat kebijakan dijalankan. Untuk itu, perlu suatu analisis cepat yang digunakan menilai suatu kebijakan yang sedang berjalan apakah bisa dilanjutkan atau tidak. Mengadopsi dari Patton dkk. (2013), quick evaluation analysis menjadi salah satu teknik yang feasible dilakukan mengingat kebijakan yang dianalisis dibatasi oleh waktu yang sangat ketat (time-constrained). Begitu pula tulisan ini, dengan lingkup waktu yang sangat singkat, satu minggu, diharapkan telah ada analisis evaluasi kebijakan PKH yang sedang berlangsung, maka quick evaluation menjadi teknik analisis yang dirasa tepat untuk digunakan.

Beberapa prinsip quick evaluation yang diberikan oleh Patton dkk. (2013), dimodifikasi untuk menyesuaikan dengan kebutuhan dan keterbatasan dari studi ini. Prinsip quick evaluation yang digunakan dalam studi ini ditandai dengan " $\mathbf{v}$ ", namun yang tidak digunakan ditandai dengan "x".

a. Menetapkan fokus evaluasi(v)

b. Berusaha terlibat dalam proses evaluasi seawal mungkin (x)

c. Menetapkan data yang akan dihasilkan (v)

d. Menentukan perubahan apa yang akan diukur (v)

e. Mengidentifikasi aksi atau intervensi kebijakan apa yang akan dievaluasi (v)

f. Menggunakan pengukuran lebih dari satu metode (x)

g. Mendesain evaluasi sedemikian rupa untuk merespon program yang dimodifikasi (v)

h. Mendesain evaluasi sehingga dapat digunakan untuk menyempurnakan program yang sudah berjalan (v)

i. Melibatkan staf pelaksana program dalam evaluasi (x)

j. Mengenali politik evaluasi (v)

k. Menyediakan temuan-temuan awal (v)

1. Melakukan presentasi secara jelas (x)

\section{HASIL DAN PEMBAHASAN}

Menetapkan Fokus Evaluasi

Fokus evaluasi dalam studi ini terkait dengan 2 (dua) persoalan yang saat ini dirasa "mengganggu dan menghambat" dalam proses implementasi PKH yaitu: 1) persoalan penggunaan dana $\mathrm{PKH}$ yang tidak sesuai peruntukannya khususnya untuk bidang kesehatan dan pendidikan dengan 
menekankan keterlibatan pendamping pada kelompok sasaran penerima bantuan PKH; dan 2) penyaluran dana PKH masih menghasilkan multiple benefeciaries atau penerima manfaat lebih dari satu program yang hal ini dapat dianalisis melalui pola kelembagaan.

\section{Menetapkan Data yang Akan Dihasilkan}

Pertama, persoalan penggunaan dana PKH yang notabene disalurkan melalui pos dan saat ini melalui online payment (menggunakan kartu peserta PKH yang berfungsi juga sebagai kartu ATM bank) ternyata masih menemui kendala di tingkat penerima bantuan PKH. Dari hasil wawancara dengan salah satu pendamping PKH di Kecamatan Srengat Kabupaten Blitar Provinsi Jawa Timur, penyaluran dana bantuan PKH melalui sistem online lebih baik dibanding melalui tunai langsung yang saat itu dilakukan oleh PT Pos Indonesia. Saat ini, penyaluran uang tersebut diberikan langsung lewat ATM ke penerima dana $\mathrm{PKH}$, dalam hal ini golongan rumah tangga sangat miskin (RTSM) yang diwakili oleh ibu rumah tangga.

Persoalan teknis di awal dan hingga kini ialah masih ada penerima bantuan (ibu rumah tangga) yang belum tahu cara menggunakan mesin ATM tersebut, belum terbiasa dengan sistem online payment, dan bahkan ada yang masih buta huruf sehingga tidak mampu membaca segala petunjuk yang ada di mesin ATM. Kendala geografis juga menjadikan mereka enggan untuk mengambil uang melalui ATM sendiri sehingga tidak sedikit mereka yang mengambil uang dilakukan secara kolektif melalui ketua kelompoknya.

Ketua kelompok di wilayah Kecamatan Srengat Kabupaten Blitar biasanya dipilih oleh anggota kelompok dengan persetujuan oleh pendamping dan diberi mandat tambahan untuk memegang kartu ATM anggotanya. Ini untuk mempermudah mereka dalam proses pengambilan uang dan meminimalisir kesalahan-kesalahan dalam penggunaan ATM seperti kartu ATM hilang, rusak, terblokir, dan lainnya. Tentunya, cara ini telah dianggap berhasil untuk mengantisipasi agar saat pembayaran, kartu ATM masih bisa digunakan dan penerima bantuan langsung mendapatkan uang (tidak ada kata terlambat untuk proses pembayaran).

Persoalan klasik yang dari program bantuan langsung tunai (BLT) dan juga dihadapi dalam PKH ini ialah penggunaan dana bantuan yang tidak semestinya oleh RTSM penerima dana PKH. Dana yang diperuntukkan untuk meningkatkan taraf kesehatan melalui cek kehamilan, imunisasi, perbaikan gizi (bidang kesehatan), membeli buku-alat tulis-seragam, membayar iuran sekolah, memenuhi kebutuhan sekolah lain (bidang pendidikan), perawatan orang lanjut usia dan pengobatan (bidang kesejahteraan sosial), justru digunakan untuk membiayai kebutuhan lain seperti membeli peralatan dapur, elektronik, membayar tagihan utang, listrik, biaya transportasi, dan sebagainya. Binarika (2012) dan Hanif dkk. (2015), menceritakan bahwa sampai saat ini, belum ada peningkatan signifikan dari siswa keluarga penerima $\mathrm{PKH}$ di bidang prestasi pendidikan.

Pada dasarnya, jika uang sudah diterima tidak ada mekanisme dan sanksi yang dirasakan secara langsung bagi penerima dana tersebut jika mereka menggunakan dana tidak sesuai peruntukannya. Namun inilah realita yang ada, kebutuhan hidup keluarga dengan kategori RTSM tidak sekedar untuk peningkatan gizi, sekolah, dan berobat, tetapi juga banyak kebutuhan lain yang sifatnya mendesak dan bisa dibilang kebutuhan pada keluarga RTSM ialah "semua kategori kebutuhan penting untuk menyambung hidup mereka". Persoalan ini sebenarnya sudah diantisipasi dengan 
menambah cakupan RTSM penerima dana PKH yaitu meliputi kesejahteraan sosial dengan memasukkan unsur lansia di atas 70 tahun agar penggunaan dana PKH lebih fleksibel namun tepat sasaran.

Di lapangan, penggunaan dana PKH yang tidak semestinya bukan sepenuhnya kesalahan dari keluarga penerima bantuan tersebut. Ada 2 (dua) kesalahan yang itu dilakukan sebelum dana disalurkan yaitu, penggunaan data survei yang out of date, karena di lapangan data yang digunakan merupakan hasil survei lima tahun ke belakang oleh rekanan dari Badan Pusat Statistik(BPS) yang itu mengakibatkan data tidak valid. Misalnya saat di survei mereka tergolong miskin, namun setelah lima tahun berjalan mereka tercukupi kebutuhan ekonominya. Studi Hanif dkk. (2015), mengungkap bahwa persoalan akurasi dan kualitas basis data sebagai pijakan program PKH masih menjadi pekerjaan rumah (PR) bagi pemerintah.

Kesalahan berikutnya ialah data hasil verifikasi (data penerima PKH baru) yang dilakukan setelah survei dari BPS untuk menentukan kepastian layak atau tidaknya keluarga tersebut menerima dana $\mathrm{PKH}$, ternyata data yang diajukan ke kecamatan, ke dinas sosial tingkat kabupaten, kemudian ke dinas sosial tingkat provinsi, hingga level Kementerian Sosial seringkali data tersebut kembali ke tingkat kecamatan tidak sesuai dengan yang diajukan. Jadi ada data yang terlewat (missed) atau berkurang jumlah penerimanya di kecamatan. Hal inilah yang kemudian menimbulkan "gesekan sosial"antara calon keluarga RTSM penerima bantuan PKH namun ternyata tidak jadi setelah data divalidasi, keluarga RTSM penerima bantuan PKH yang menerima bantuan,dan dengan tim pendamping mereka.

Kasus di Kecamatan SrengatKabupaten Blitar, gesekan sosial tersebut juga terjadiakibatadanya keluarga penerima bantuan PKH yang ternyata menggunakan dana tidak sesuai peruntukkannya namun memiliki semacam "kekuatan" untuk menentang arahan dan nasehat dari pendamping dikarenakan usia yang lebih tua dari pendamping, berpengaruh di komunitasnya, dan memiliki akses ke media massa dan lembaga swadaya masyarakat (LSM). Gesekan ini tidak terlepas dari faktor budaya masyarakat di wilayah Blitar yang masih mengedepankan unggah-ungguh dalam berinteraksi sosial.

Kedua, penyaluran dana PKH masih menghasilkan multiple benefeciaries atau penerima manfaat lebih dari satu program. Ini berkaitan dengan pola kelembagaan yang dijalankan oleh pemerintah, dalam hal ini Kementerian Sosial sebagai leading sectordi kebijakan PKH yang bersinggungan dengan instansi lain pemberi bantuan pada masyarakat miskin seperti Kementerian Pendidikan dan Kebudayaan (Kemendikbud), Kementerian Kelautan dan Perikanan (KKP), Kementerian Energi dan Sumber Daya Mineral (Kemen ESDM), Kementerian Pertanian (Kementan), dan instansi pemerintah lainnya (Hikmat, 2017). Instansi-instansi tersebut juga memberikan bantuan dengan bentuk lain kepada keluarga miskin dengan indikator berbeda.

Bentuk dan indikator bantuan yang diberikan oleh berbagai kementerian kepada masyarakat miskin justru berhimpitan dengan indikator keluarga miskin penerima PKH. Di lapangan, Hanif dkk. (2015), dan Hikmat (2017), juga menyatakan bahwa banyaknya masyarakat miskin penerima bantuan dari pemerintah menjadikan keluarga RTSM menerima bantuan tidak hanya dari PKH, melainkan juga dari program lain seperti program Indonesia sehat, program Indonesia pintar, subsidi listrik, subsidi gas, subsidi pupuk, subsidi bibit, bantuan rastra, dan lainnya. Sayangnya, Susenas tidak memiliki 
data penerima PKH tahun 2016, namun memiliki data penerima bantuan program pemerintah lain tersebut.

\section{Menentukan Perubahan Apa yang Akan Diukur}

Perubahan-perubahan yang akan diukur dan dilakukan dalam evaluasi kebijakan PKH terkait dengan permasalahan yang dihadapi saat ini, kondisi yang ada, dan kemana arah perbaikan kebijakan yang akan dilakukan (policy guidances). Untuk itu, ada 2 (dua) perubahan kebijakan yang akan dilakukan sebagaimana pada Tabel 1 .

Mengidentifikasi Aksi atau Intervensi Kebijakan Apa yang Akan Dievaluasi

Sebagai aktor utama pelaksana kebijakan PKH, Kementerian Sosial (Menteri sebagai pengarah) melalui Direktorat Jenderal Perlindungan dan Jaminan Sosial (sebagai ketua) dan Direktur Jaminan Sosial
Keluarga (sebagai sekretaris) memiliki tugas (Hikmat, 2017):

a. Mengkaji berbagai rencana operasional yang disiapkan oleh direktorat teknis pelaksana $\mathrm{PKH}$;

b. Melakukan koordinasi lintas sektor terkait agar tujuan PKH dapat berjalan baik;

c. Membentuk tim lintas sektor yang terdiri dari perwakilan kementerian/ lembaga terkait;

d. Tim lintas sektor bertugas menentukan sasaran Keluarga Penerima Manfaat PKH; dan

e. Melakukan pengawasan pelaksanaan PKH

Tugas-tugas teknis tersebut dijalankan secara vertikal ke bawah dan ditindaklanjuti dengan pembentukan tim pelaksana pusat PKH mulai dari level pusat oleh

Tabel 1. Perubahan-perubahan Kebijakan yang Diukur dan Aktor Penanggung Jawabnya

\begin{tabular}{|c|c|c|c|}
\hline No & $\begin{array}{c}\text { Perubahan yang } \\
\text { diharapkan }\end{array}$ & $\begin{array}{c}\text { Arah kebijakan yang } \\
\text { diinginkan }\end{array}$ & $\begin{array}{c}\text { Aktor/lembaga } \\
\text { penanggung jawab }\end{array}$ \\
\hline 1 & $\begin{array}{l}\text { Penggunaan dana bantuan } \\
\text { PKH oleh keluarga } \\
\text { penerima bantuan tersebut } \\
\text { sesuai peruntukannya } \\
\text { yaitu untuk meningkatkan } \\
\text { kualitas kesehatan, } \\
\text { m e n i n g k a t k a n } \\
\text { taraf pendidikan, } \\
\text { dan meningkatkan } \\
\text { kesejahteraan sosial }\end{array}$ & $\begin{array}{l}\text { 1. Kebijakan pemutakhiran } \\
\text { data keluarga miskin } \\
\text { 2. Kebijakan penguatan } \\
\text { kompetensi, mental, dan } \\
\text { keahlian tim pendamping } \\
\text { melalui pelatihan dan } \\
\text { pendidikan singkat dengan } \\
\text { memperbanyak aspek ilmu } \\
\text { sosiologi, komunikasi, dan } \\
\text { budaya }\end{array}$ & $\begin{array}{l}\text { 1. Badan Pusat Statistik, } \\
\text { Kementerian Sosial } \\
\text { 2. Pendamping } \\
\text { lapangan, staf di } \\
\text { kecamatan dan desa } \\
\text { didukung dinas sosial } \\
\text { kabupaten/kota, }\end{array}$ \\
\hline 2 & $\begin{array}{l}\text { Keluarga miskin } \\
\text { dipastikan menerima satu } \\
\text { jenis dari segala bantuan } \\
\text { sosial dari pemerintah } \\
\text { (single beneficiary) }\end{array}$ & $\begin{array}{l}\text { Mengintegrasikan segala } \\
\text { bentuk bantuan pemerintah } \\
\text { kepada keluarga miskin ke } \\
\text { dalam skema satu bantuan } \\
\text { sosial. PKH bisa menjadi induk/ } \\
\text { komplementer dari seluruh } \\
\text { nama bantuan sosial yang } \\
\text { diselenggarakan pemerintah }\end{array}$ & $\begin{array}{l}\text { Kementerian } \\
\text { Kementerian Pendidikan dan } \\
\text { Kebudayaan, Kementerian } \\
\text { Kelautan dan Perikanan, } \\
\text { Kementerian Energi dan } \\
\text { Sumber Daya Mineral, } \\
\text { Kementerian Pertanian, } \\
\text { kementerian/lembag a } \\
\text { lainnya, dan pemerintah } \\
\text { daerah }\end{array}$ \\
\hline
\end{tabular}

Sumber: Data Diolah, 2017 
Kementerian Sosial, pelaksana koordinasi dan teknis PKH di level provinsi oleh dinas sosial provinsi, pelaksana koordinasi dan teknis PKH di level kabupaten/kota oleh dinas sosial kabupaten/kota, pelaksana teknis PKH di level kecamatan oleh bidang urusan sosial kesejahteraan yang diteruskan oleh para pendamping yang langsung bersentuhan dengan keluarga RTSM penerima bantuan PKH. Struktur ini masih dirasa efektif dalam memberdayakan keluarga penerima bantuan PKH dengan mengoptimalkan peran pendamping di lapangan.

Kementerian Sosial juga menjadi aktor pelaksana utama dalam mengoordinasikan berbagai aspek terkait implementasi kebijakan PKH. Sebagai pelaksana harian dibawah koordinasi Menteri Koordinator Pembangunan Manusia dan Kebudayaan (Menko PMK), Menteri Sosial dengan anggota dari eselon I yang membidangi urusan pengentasan kemiskinan, pendidikan, kesehatan, anak, keluarga, disabilitas, lanjut usia, data, komunikasi, juga melakukan koordinasi terhadap instansi lain seperti Kementerian PPN/Bappenas, Kementerian Kesehatan, Kementerian Pendidikan dan Kebudayaan, Kementerian Agama, Kementerian Dalam Negeri (termasuk di dalamnya pemerintah daerah) (Hikmat, 2017), dan juga Badan Pusat Statistik.

Tugas koordinasi dan teknis yang diemban oleh Kementerian Sosial ini kemudian melahirkan aksi-aksi nyata sebagai bentuk intervensi pemerintah untuk memperbaiki: 1) kebijakan pemutakhiran data keluarga miskin, 2) kebijakan penguatan kompetensi, mental, dan keahlian tim pendamping melalui pelatihan dan pendidikan, serta 3) kebijakan yang mengintegrasikan segala bentuk bantuan pemerintah kepada keluarga miskin ke dalam skema satu bantuan sosial (dibawah skema PKH).

\section{Mendesain Evaluasi Untuk Merespon Program yang Dimodifikasi}

Kebijakan pemutakhiran data penerima bantuan PKH telah menjadi salah satu aksi Kementerian Sosial saat ini. Selain dengan mengerahkan tim pendamping di lapangan (kasus di wilayah Kecamatan Srengat Kabupaten Blitar), juga dengan melibatkan BPS setempat untuk melakukan verifikasi data terbaru. Namun demikian, persoalan lain muncul yaitu data yang "dikirim" dari tim pendamping ke kecamatan-dinas sosial kabupaten/kota seringkali setelah data sampai di level pusat (Kementerian Sosial) dan kembali ke kecamatan tidak sesuai dengan jumlah dan nama penerima saat awal data dikirim oleh tim pendamping melalui verifikator. Untuk itu, perlu dilakukan perbaikan terhadap skema pendataan bagi keluarga penerima bantuan PKH dengan melibatkan multi stakeholders terkait.

Fakta bahwa keluarga penerima bantuan PKH sering "tidak menggunakan dana bantuan" tidak sesuai peruntukkannya, membutuhkan pendekatan emosional yang kuat dan erat antara tim pendamping dengan keluarga penerima bantuan. Kebijakan untuk penguatan kompetensi, mental, dan keahlian tim pendamping perlu dilakukan melalui berbagai bentuk pendidikan dan pelatihan, workshop, dan mentoring dari pendamping senior. Kegiatan tersebut dilakukan tidak hanya saat mereka direkrut, namun juga intens dilakukan sepanjang mereka melakukan pendampingan pada keluarga penerima bantuan PKH. Aspek sosiologi, komunikasi, dan budaya menjadi penting mengingat mereka harus berhadapan dengan "berbagai individu di suatu masyarakat dengan karakter berbeda" sehingga gesekan sosial seringkali terjadi, terutama terkait dengan penetapan penerima bantuan dan penyaluran dana.

Kementerian Sosial yang diberi mandat untuk mengordinasikan dan menjalankan kegiatan harian $\mathrm{PKH}$ memiliki 
wewenang untuk mengubah kebijakan agar skema keluarga miskin penerima bantuan menjadi single benefeciary, yaitu satu keluarga miskin menerima satu program bantuan yang sesuai kebutuhan mereka. Program komplementer PKH ialah memodifikasi kebijakan PKH yang ada untuk kemudian disinergikan dengan paket kebijakan bantuan lainnya di Indonesia.

Bidang kelembagaan menjadi penting mengingat keluarga miskin menerima lebih dari satu program bantuan pemerintah, tidak hanya PKH. Hal ini terjadi tidak hanya di Kabupaten Blitar, namun juga di Kabupaten Bima (Provinsi Nusa Tenggara Barat) dan Kabupaten Sidoarjo (Provinsi Jawa Timur) (Hanif dkk., 2015). Sebagai koordinator program jaminan dan perlindungan sosial nasional, Kementerian Sosial ingin mengintegrasikan berbagai skema bantuan pemerintah kepada masyarakat miskin melalui "program komplementer PKH". Tentu ini melibatkan berbagai lembaga pemerintah lain mulai dari Kementerian Pendidikan dan Kebudayaan, Kementerian Kelautan dan Perikanan, Kementerian Energi dan Sumber Daya Mineral, Kementerian Pertanian, kementerian/ lembaga lainnya, dan pemerintah daerah.

Di level daerah, studi Hanif dkk. (2015), menunjukkan bahwa kepala daerah di Kabupaten Bima-NTB dan Kabupaten Sidoarjo-Jawa Timur mendukung $\mathrm{PKH}$ sebagai bagian kebijakan untuk pengentasan kemiskinan masyarakat di daerahnya. Sayangnya, kebijakan PKH yang itu berasal dari anggaran Kementerian Sosial yang diturunkan ke dinas sosial kabupaten/kota masih belum terintegrasi dengan program pengentasan kemiskinan sejenis yang ada di lingkup kabupaten/kota, baik yang itu program dari dinas lokal setempat atau terlebih program bantuan masyarakat dari dinas-dinas lainnya. Ini terlihat dari tidak ada koordinasi antara tim penanggulangan kemiskinan daerah yang diinisasi oleh Badan Perencanaan Pembangunan Daerah setempat terkait skema pemberian bantuan sosial ke masyarakat miskin.

\section{Mendesain Evaluasi Untuk Me- nyempurnakan Program yang Sudah Berjalan}

Program-program yang sudah berjalan dievaluasi sesuai dengan rencana aktor pelaksana teknis dan koordinator antar lembaga (lintas sektoral), dalam hal ini Kementerian Sosial. Paling tidak ada 3 (tiga) kebijakan yang harus dievaluasi dan didesain ulang oleh Kementerian Sosial agar sesuai dengan tujuan kebijakan PKH yaitu:1) Kebijakan pemutakhiran data keluarga miskin penerima $\mathrm{PKH}$; 2) Kebijakan penguatan kompetensi dan kapasitas tim pendamping; 3) Kebijakan pengintegrasian satu pintu penerima bantuan pemerintah melalui skema komplementer PKH.

Kebijakan pemutakhiran data sudah dilakukan oleh Kementerian Sosial yang bekerjasama dengan Badan Pusat Statistik (BPS) dan pemerintah provinsi/kabupaten/ kota melalui sistem pemutakhiran data online dengan melibatkan tim pendamping sebagai garda terdepan untuk kemudian diverifikasi oleh petugas di fasilitas pendidikan, di fasilitas kesehatan, dan di fasilitas kesejahteraan sosial sebelum naik ke level dinas sosial kabupaten/kota, dinas sosial provinsi dan Kementerian Sosial. Di level Kementerian Sosial, penguatan dan pemutakhiran data dilakukan melalui Pusat Data dan Informasi dengan arahan dari Direktorat Jenderal Perlindungan dan Jaminan Sosial.

Peningkatan kompetensi dan kapasitas tim pendamping harus senantiasa ditingkatkan mengingat saat ini kebijakan PKH dilengkapi dengan sistem pengaduan masyarakatPKH(SPM-PKH)(Kementerian Sosial, 2013; Hikmat, 2017). Beberapa program yang difasilitasi Kementerian Sosial untuk penguatan kompetensi dan kapasitas tim pendamping antara lain 
workshop, rapat koordinasi, bimbingan teknis,e-learning, dan sosialisasi. Hal ini terkait tugas pendamping tiap bulan yaitu pendamping $\mathrm{PKH}$ berkewajiban memastikan bantuan komponen kesehatan danpendidikan sampai kepada sasaran, dan memenuhi kriteria bagi penyandang disabilitas dan lanjut usia (Kementerian Sosial, 2016).

Hasil wawancara dengan tim pendamping PKH di Kecamatan Srengat Kabupaten Blitar, tim pendamping diberi briefing dan pelatihan terkait apa saja yang akan dilakukan saat pendampingan tersebut. Namun hal ini dilakukan sekali selama dia menjadi pendamping, yaitu saat awal rekrutmen. Namun, ada kegiatan perkumpulan program family development session (FDS) dengan presentasi dan memutar video yang dihadiri 30 anggota (tim pendamping) yang dilakukan setiap satu bulan sekali untuk berbagi materi terkait apa saja kendala dan capaian PKH untuk kemudian disampaikan dan didiskusikan bersama tim pendamping lainnya sebagai bahan evaluasi untuk kegiatan pendampingan ke depan.

\section{Mengenali Politik Evaluasi}

Politik evaluasi perlu diketahui untuk menyamakan visi-misi dan persepsi antar aktor pelaksana baik di level koordinasi dan teknis. Berhubung ini kebijakan level nasional yang mencakup seluruh wilayah Indonesia, maka melihat konstelasi atau minimal dukungan politik dari pemerintah yang berkuasa saat ini dianggap relevan. Dalam hal ini, kondisi politik lokal baik di level provinsi maupun kabupaten/kota diasumsikan satu arus/sepemahaman dengan politik nasional. Hal ini karena apapun yang dilakukan oleh pemerintah pusat, terutama terkait pendanaan dan bantuan sosial di daerah, maka elit politik lokal pasti mengikuti dan bahkan mendukung apa yang dilakukan oleh pemerintah pusat.
Secara politik nasional, Presiden Joko Widodo telah menginstrusikan dalam rapat terbatas tentang keuangan inklusif pada tanggal 26 April 2016 yang menyebutkan:

a. Perumusan strategi nasional keuangan inklusif ditindaklanjuti oleh Menko Perekonomian.

b. Setiap bantuan sosial dan subsidi disalurkan secara non-tunai dan menggunakan sistem perbankan untuk kemudahan mengontrol, memantau, dan mengurangi penyimpangan. Penggunaan sistem perbankan dengan memanfaatkan keuangan digital dimaksudkan untuk mendukung perilaku produktif dan memperluas inklusi keuangan.

c. Penggunaan beragam kartu dalam menyalurkan dana bantuan sosial agar dapat diintegrasikan dalam satu kartu dan disalurkan secara non-tunai untuk semua bantuan agar dikoordinasikan oleh Menko Pembangunan Manusia dan Kebudayaan (Hikmat, 2017).

Dukungan presiden tentu menjadi dasar kuat dari aspek politik implementasi PKH dan berbagai bentuk evaluasinya. Sebagai suatu kebijakan, anggota Dewan Perwakilan Rakyat (DPR) dan Dewan Perwakilan Daerah (DPD) Republik Indonesia seringkali memberikan masukan terhadap implementasi PKH agar tepat sasarannya. Tentu ini tidak terlepas dari dukungan kepala daerah dan dewan perwakilan rakyat daerah (DPRD) terkait mandat dan capaian kerja mereka bagi konsituen pemilih di daerahnya agar tidak terjadi kesenjangan kemiskinan dan menghindari gejolak sosial. Dengan kata lain, evaluasi implementasi PKH tidak mengalami hambatan di aspek politik pusat dan daerah, justru hal ini mendapat dukungan langsung dari Presiden Republik Indonesia, DPR, DPD, gubernur, bupati/ walikota, DPRD. 
Menyediakan Temuan-temuan Awal

Studi ini telah menilai beberapa kekurangan implementasi PKH yang sedang berjalan saat ini. Sebenarnya, apa yang menjadi kekurangan $\mathrm{PKH}$ sebelumnya sudah mulai diperbaiki dan direncakan sistem perbaikannya oleh pemerintah. Beberapa program perbaikan $\mathrm{PKH}$ yang telah mendapat perbaikan dan rencana program terkait dengan 3 (tiga) hal yaitu: 1) pemutakhiran data penerima bantuan $\mathrm{PKH}$; 2) peningkatan kompetensi dan keahlian tim pendamping; dan 3) penyatuan sistem penerima bantuan PKH dengan skema bantuan lain sebagai program komlementer PKH.

Ketiga perbaikan kebijakan tersebut sebenarnya sudah menjadi bagian upaya monitoring dan evaluasi rutin dari pihak Badan Perencanaan dan Pembangunan Nasional (Bappenas). Program evaluasi hal tersebut telah menunjukkan bahwa temuanstudi ini terkait evaluasi program PKH yang memang perlu diperbaiki (Gambar 2).

Temuan awal studi ini terkait beberapa evaluasi program pemutakhiran data ialah perubahan cakupan sasaran peserta $\mathrm{PKH}$ Tahun 2007, Rumah Tangga Sangat Miskin (RTSM) (7\% terbawah pada BDT). Tahun 2012 Keluarga Sangat Miskin (KSM) yaitu ayah,ibu, dan anak. Tahun 2016, sasaran peserta PKH bukan lagi KSM (7\% terbawah pada BDT) melainkan Keluarga Miskin (KM) atau 13\% terbawah pada BDT. Perubahan ini untuk mengakomodasi prinsip bahwa keluarga adalah satu unit yang sangat relevan dengan peningkatan kualitas sumber daya manusia termasuk di dalamnya ada bantuan untuk penyandang disabilitas dan kesejahteraan sosial (Kementerian Sosial, 2016).

Program peningkatan keahlian dan kompetensi tim pendamping $\mathrm{PKH}$ dilakukan melalui berbagai bentuk pelatihan baik secara internal dengan tim pendamping maupun dengan kelompok penerima bantuan PKH. Pembekalan tim pendamping dengan keluarga penerima bantuan PKH dilakukan melalui pelatihan kreativitas dan berbagai hal untuk meningkatkan perekonomian keluarga penerima $\mathrm{PKH}$. Hal ini dilakukan oleh tim pendamping PKH di Kabupaten Blitar selain kesadaran pendidikan, kesehatan, dan kesejahteraan sosial.

Tim pendamping diharapkan dapat mensukseskan verifikasi data bagi mereka yang benar-benar layak menerima bantuan dan memanfaatkan bantuan tersebut dengan benar. Kementerian Sosial (2016), memberlakukan mekanisme sanksi sebagai berikut: jika pendamping yang peserta PKH dampinganya tidak memenuhi kondisionalitas akan diberikan sanksi dapat berupa teguran secara lisan maupun tertulis

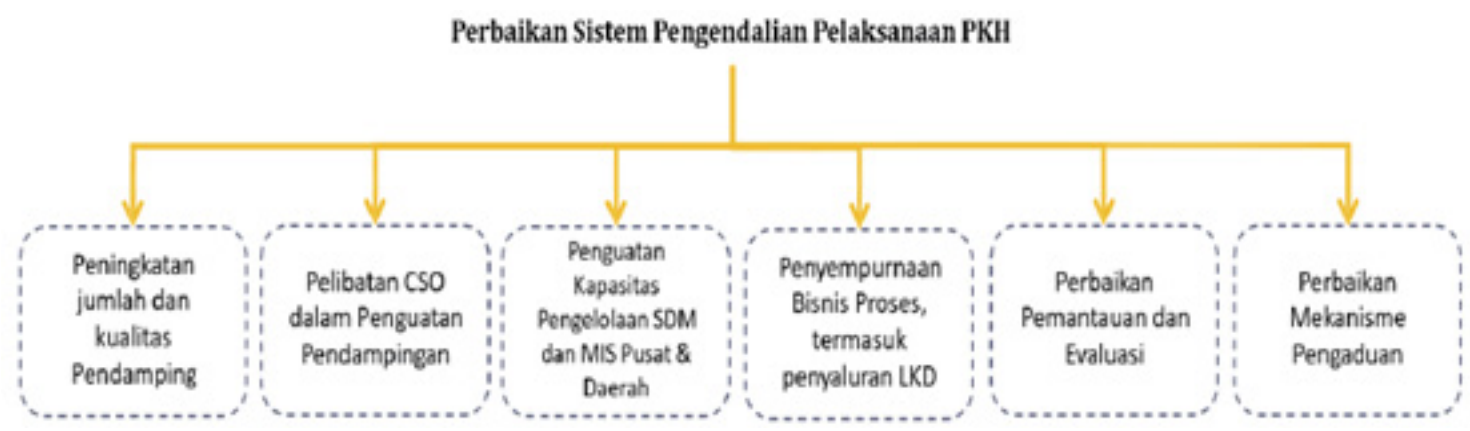

Sumber: Bappenas dalam Kementerian Sosial, 2016

\section{Gambar 2}

Perbaikan Sistem Pengendalian Pelaksanaan PKH 
(SP-1 sd SP-3), penundaan pembayaran honorarium, dan penghentian kontrak kerja kepada pendamping tersebut.

Pola kelembagaan untuk mengintegrasikan sistem penerima bantuan sosial PKH melalui sistem komplementer PKH telah direncanakan oleh Kementerian Sosial yang melibatkan berbagai lintas sektor terkait. Perbaikan kelembagaan agar PKH menjadi sentral dari program komplementer lain ialah melalui perbaikan peraturan perundang-undangan nasional dan definisi tentang siapa golongan masyarakat miskin penerima bantuan dengan kriteria tertentu yang nantinya menjadi bagian dari bantuan serupa yang dilakukan oleh kementerian/lembaga pusat selama ini.

Secara menyeluruh, upaya pemutakhiran data, peningkatan kompetensi tim pendamping, pengintegrasian penerima manfaat bantuan tersebut telah menjadi bagian dari alur kerja PKH. Alur kerja PKH terdiri atas lima kegiatan utama yaitu: 1. Penetapan Sasaran (targeting); 2. Seleksi Sumber Daya Manusia (SDM); 3. Pendidikan dan Pelatihan; 4. Pelaksanaan PKH selama enam tahun; dan 5 Transformasi (Kementerian Sosial, 2016)
Di bidang kelembagaan, Kementerian Sosial dengan stakeholders lain melakukan berbagai aktivitas lintas sektoral seperti Rapat Koordinasi tingkat Pusat (Rakorpus), Rapat Koordinasi Nasional (Rakornas), Rapat Koordinasi Daerah (provinsi dan kabupaten/kota), Bimbingan Teknis, E-Learning, dan Monitoring Evaluasi dan Sistem Penanganan Pengaduan (Kementerian Sosial, 2016). Praktiknya, koordinasi lintas sektor yang dilakukan dengan melibatkan kementerian/lembaga paling tidak dikoordinasi oleh kementerian koordinator (Gambar 3).

Landasan hukum dan otoritas Kementerian Sosial sebagai ketua pelaksana penyelenggaraan $\mathrm{PKH}$ menjadi dasar bagi Kementerian Sosial untuk menggerakkan kementerian/lembaga lain agar bersatu dan terintegrasi dan terkoordinasi dalam implementasi PKH. Hal ini tentu telah dilakukan oleh Kementerian Sosial dengan melakukan berbagai perubahan/penyesuaian terhadap kebijakan PKH sesuai fenomena yang ada. Penilaian dan perbaikan terhadap program-program pendukung yang dirasa kurang telah mulai diperbaiki. Hal ini tentu relatif lebih terimplementatif dengan baik

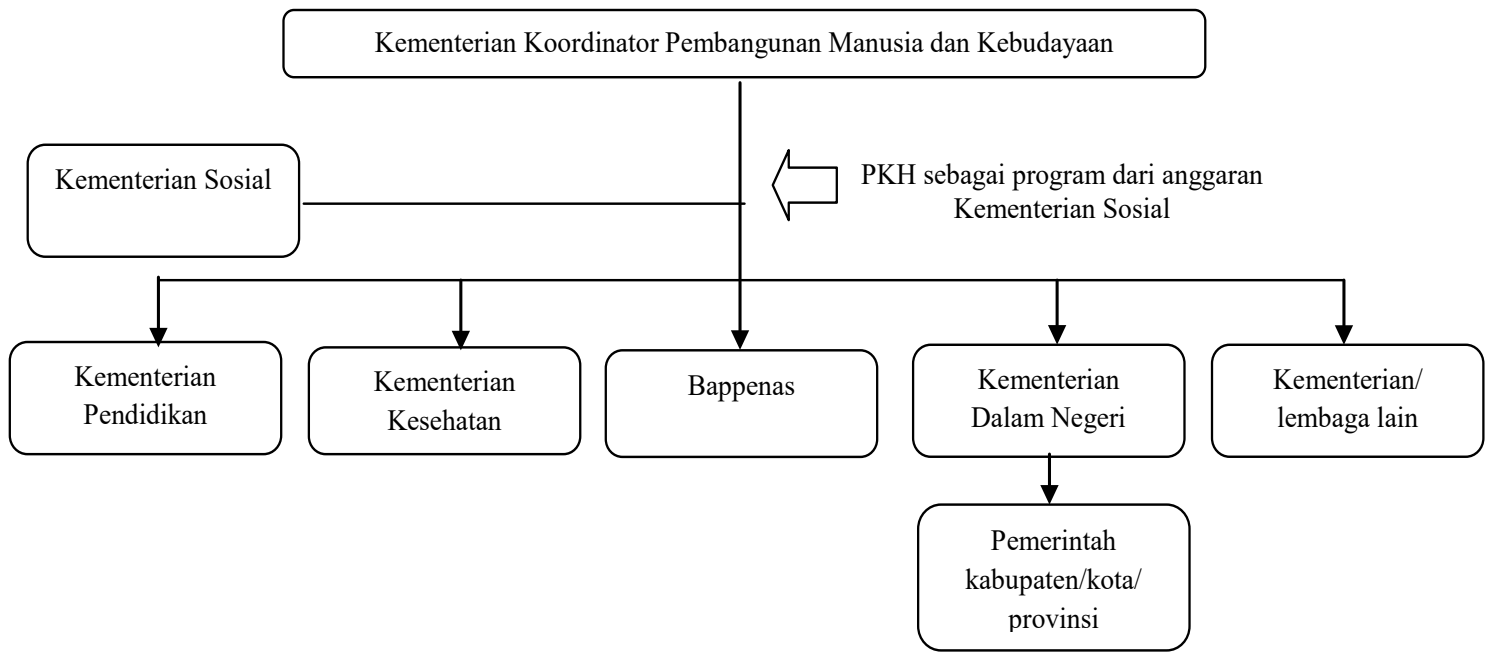

Sumber: Diinterpretasi dari Kementerian Sosial (2016) dan Hikmat (2017)

Gambar 3

Koordinasi Teknis Pelaksanaan PKH antar Lembaga 


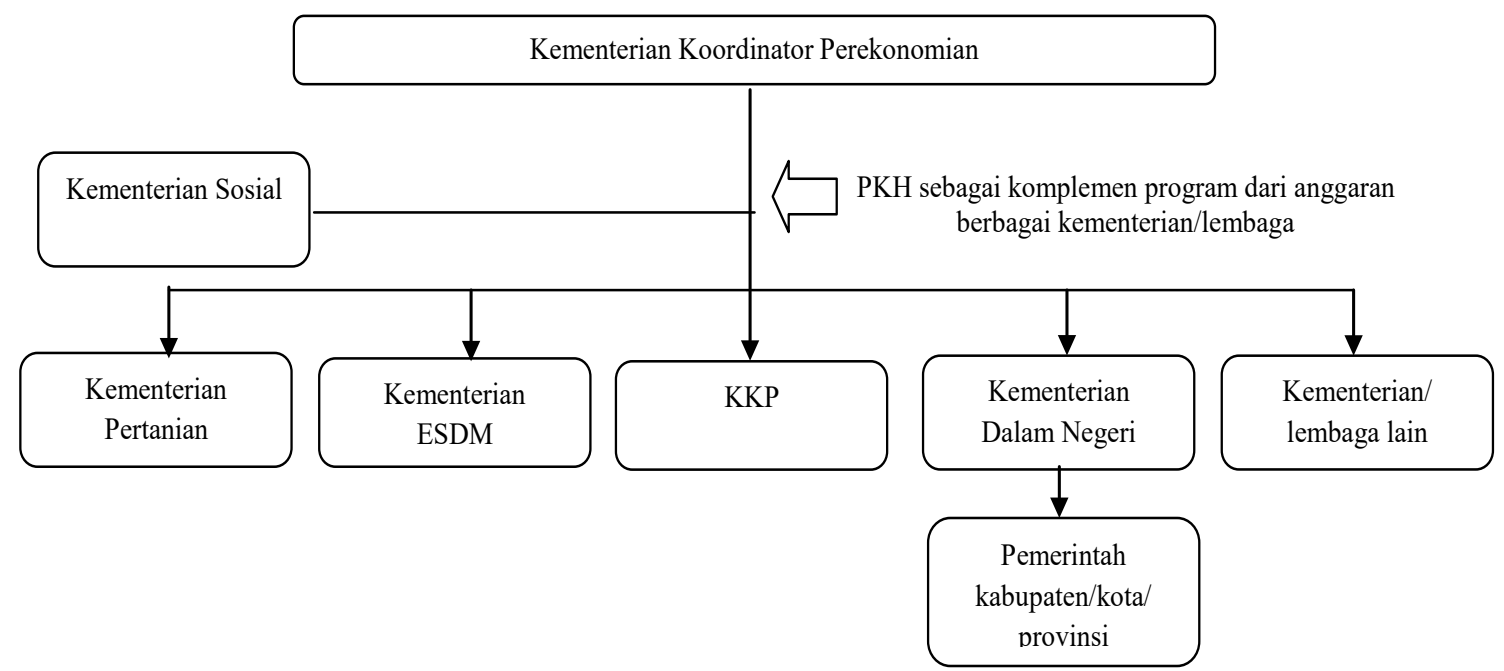

Sumber: Diinterpretasi dari Kementerian Sosial (2016) dan Hikmat (2017)

\section{Gambar 4}

\section{Rencana Koordinasi Lintas Sektoral PKH sebagai Komplementer Bantuan Sosial}

mengingat sumber pendanaan PKH berasal dari anggaran Kementerian Sosial yang hal itu akan menjadi wewenang penuh Kementerian Sosial dalam mengoptimalkan kebijakan PKH di lapangan.

Rencana Kementerian Sosial dalam mengintegrasikan berbagai program bantuan kepada keluarga miskin dilakukan dengan skema kolaborasi antar kementerian/lembaga yang memiliki program bantuan sejenis. Kementerian Sosial mengusung konsep "PKH sebagai komplementer" dengan bantuan sosial lainnya, agar PKH menjadi program terpadu dengan program bantuan lain yang dianggarkan di tiap kementerian/lembaga di Indonesia. Ini tentu membutuhkan upaya besar dari segi waktu, tenaga, biaya, dan sumber daya lainnya mengingat persoalan koordinasi antar lembaga di Indonesia yang itu menyangkut alokasi (sharing) pendanaan, perubahan wewenang, dan tarik ulur kepentingan menjadi isu klasik saat ini (Gambar 4).

Studi Triyono(2011), mengungkapkan bahwa koordinasi antar lembaga di Indonesia menjadi tantangan sendiri dalam praktiknya, dan hal ini tidaklah mudah dijalankan. Hampir semua sektor dan lembaga memiliki kepentingannya sendiri yang mengakibatkan mereka berjalan sesuai dengan pedoman dan rencana kerja di tiap lembaga. Hal ini diperburuk dengan kondisi peraturan perundangan di Indonesia yang terkesan carut dan marut masih terdapat celah dan kelemahan yang membuat koordinasi antar lembaga publik tidak sinkron.

Temuan-temuan awal ini mengindikasikan bahwa sebenarnya apa yang menjadi kekurangan dari sistem pelaksanaan $\mathrm{PKH}$ telah dievaluasi dan dilakukan perbaikan baik berupa program teknis yang sedang dijalankan (internal) serta rencana kerja yang berhubungan dengan antar lintas sektor (eksternal). Namun demikian, persoalan-persoalan di lapangan untuk melakukan perbaikan tersebut tidaklah mudah mengingat banyak aspek teknis dan non-teknis yang perlu dilakukan dalam membuat suatu pekerjaan tersebut dapat selesai tepat waktu.

Faktor-faktor yang mempengaruhi kegiatan tersebut bisa saja dari sumber daya manusia (SDM) pelaksana yang kurang kompeten, gaya birokrasi yang terkesan kaku dan lamban, atau masih adanya ego masing-masing lembaga untuk "terkesan 
mementingkan program di lembaga dia yang bersangkutan, namun terkesan mengganggap tidak penting program dari lembaga lain" meskipun kadangkala itu dalam satu unit kementerian koordinator yang sama atau dalam satu unit lembaga/ kementerian yang sama. Ego sektoral ialah kunci dalam koordinasi antar lembaga baik di level pusat dan daerah yang saat ini menjadi salah satu persoalan klasik birokrasi di Indonesia.

\section{SIMPULAN}

Dari pembahasan sebagaimana telah disampaikan, terdapat beberapa simpulan dalam penelitian ini. Masih banyak keluarga penerima $\mathrm{PKH}$ ternyata setelah diverifikasi oleh tim pendamping sudah tidak layak masuk menjadi golongan rumah tangga sangat miskin (RTSM) karena data yang didapatkan sudah sekitar 3-5 tahun yang lalu. RTSM penerima PKH belum semuanya menggunakan uang tersebut untuk meningkatkan kesehatan atau memeriksakan diri mereka ke puskemas. Begitu pula di sektor pendidikan dimana mereka kurang sadar untuk membekali anak-anak mereka membeli buku terbaru atau sebagai biaya penunjang pendidikan lainnya. Meskipun belum banyak evaluasi terhadap program $\mathrm{PKH}$, namun penggunaan dana untuk hal tersebut masih digunakan untuk menutupi kebutuhan hidup sehari-hari pada RTSM. Memang tidak ada indikator atau skema khusus agar dana tunai tersebut digunakan tepat sesuai peruntukkannya, kecuali melalui monitoring. Bahwa sebenarnya telah dilakukan evaluasi dan perbaikan dalam pelaksanaan program PKH, namun terkendala oleh masalah sumberdaya manusia yang tidak kompeten, birokrasi yang masih terkesan kaku serta adanya ego sektoral lembaga/kementerian sehingga dalammengintegrasikan $\mathrm{PKH}$ dengan program lain agar menjadi single beneficiary menyisakan pekerjaan rumah (PR) bagi Kementerian Sosial dengan lembaga/kementerian lain (lintas sektor). Upaya ini akan menghadapi tantangan yang cukup "rumit" dan terkesan "sulit" mengingat koordinasi antar lintas sektor menjadi persoalan klasik yang dihadapi oleh agen-agen publik di Indonesia. Pengalihan wewenang, berbagi (sharing)pendanaan, dan perbedaan kepentingan menjadi "alasan kontemporer" yang masih dipakai saat ini, sekalipun itu dikoordinasikan oleh kementerian koordinator. Belum lagi persoalan peraturan perundangan yang tumpang-tindih, menjadikan sistem integrasi PKH dengan program bantuan sejenis yang dianggarkan dari kementerian/ lembaga dan pemerintah daerah masih dipertanyakan. Terkait 2 (dua) persoalan utama dalam tulisan ini, yaitu bagaimana agar dana $\mathrm{PKH}$ digunakan sesuai peruntukkannya; dan keluarga penerima bantuan ialah mereka yang hanya menerima satu paket bantuan dari pemerintah, maka ada beberapa rekomendasi kebijakan yang diberikan antara lain: 1) Evaluasi pemutakhiran data sebaiknya dapat dilakukan secara online yang langsung dapat dilakukan oleh tim pendamping dilapangan dan terhubung dengan dinas sosial kabupaten/kotaprovinsi, Badan Pusat Statistik, dan Kementerian Sosial. Sistem tersebut sebaiknya dapat menjadi komunikasi antara tim pendamping dengan dinas sosial hingga level Kementerian Sosial. Peran BPS tentu juga esensial untuk memastikan kevalidan dan keabsolutan data secara nasional. Penggunaan aplikasi khusus dengan smartphone sebaiknya mulai digunakan dengan membentuk "grup komunikasi” antar aktor (pendampingdinas sosial kabupaten/kpta/provinsikementerian sosial-bps) agar mereka dapat segera merespon dan menyelesaikan persoalan terkait validitas data penerima PKH. 2) Pembekalan bagi tim pendamping baik pendidikan dan pelatihan, workshop, sosialisasi atau bentuk peningkatan kompetensi mereka, sebaiknya dilakukan 
dengan menerima masukan-masukan mereka untuk kemudian dijadikan sebagai ide dalam materi pendidikan dan pelatihan tersebut. Model peningkatan kompetensi sebaiknya berasal dari bottom-up (tim pendamping), bukan hanya dari top-down (Kementerian Sosial). Karena sebagai garda terdepan, tim pendamping memiliki berbagai persoalan yang itu berarti "lain pendamping, lain cerita, dan lain daerah lain pula persoalannya". 3)Mengintegrasikan berbagai program bantuan sosial agar menjadi single beneficiary, membutuhkan koordinasi antar lintas sektor antara lembaga pemerintah. Dalam hal ini, Kementerian Sosial sebagai motor untuk mengintegrasikan program bantuan serupa. Ada 2 (dua) hal yang disarankan untuk level koordinasi terkait hal tersebut. Pertama, penguatan regulasi selevel peraturan presiden (perpres) atau bahkan peraturan pemerintah (PP) yang hal tersebut menjadi kewenangan lebih kuat bagi Kementerian Sosial untuk menjalankan program komplementer PKH. Kedua menyusun program bersama kementerian/lembaga dengan dasar Rencana Pembangunan Jangka Menengah (RPJMN) di bidang jaminan sosial dan perlindungan keluarga miskin dengan berbagai skema bantuan. Program ini melibatkan lintas sektor sebagai pelaksana teknis dan koordinasinya dengan pola "pergantian pengurus" setiap satu tahun sekali. Hal ini ditujukan agar timbul rasa memiliki terhadap program bantuan tersebut.

\section{DAFTAR PUSTAKA}

Alamin, A. R. (2010). Analisis Peran Pendamping Dalam Program Keluarga Harapan (PKH) Pada Suku Dinas Sosial Jakarta Utara. Skripsi. Jurusan Pengembangan Masyarakat Islam - Fakultas Dakwah dan Komunikasi Universitas Islam Negeri Syarif Hidayatullah Jakarta.

Binarika, C. D. (2012). Partisipasi Rumah Tangga Sangat Miskin (RTSM) Dalam Program Keluarga Harapan (PKH) Pendidikan di Kelurahan Latsari Kecamatan Tuban Kabupaten Tuban. Skripsi. Jurusan Administrasi NegaraFakultas Ilmu Sosial dan PolitikUniversitas Pembangunan Nasional Veteran Jawa Timur Surabaya.

CDC. Tanpa Tahun. Step by StepEvaluating Violence and Injury Prevention Policies. Policy Brief 1: Overview of Policy Evaluation. Diakses tanggal 19 Oktober 2017 dari https://www.cdc.gov/injury/ pdfs/policy/Brief\%201-a.pdf.

Davies, Philip. (2008). Using Monitoring and Evaluation to Improve Public Policy. SRA Workshop on 10 March 2008 in British Library Conference Centre, London, United Kingdom. 
Hanif, Hasrul; Dati, Fatimah; Aminatun, Zubaedah; Juhriati, Kanis, Suvianita; Widyatama, A; Zuhrah, Maci. (2015). Mewujudkan Program Keluarga Harapan (PKH) yang Lebih Bermakna. Analisa Gender Terhadap Implementasi PKH di Kabupaten Sidoarjo (Jawa Timur) dan Kabupaten Bima (NTB). Jakarta: FriedrichEbert-Stiftung Bekerja sama dengan Kementerian Koordinator Pembangunan Manusia dan Kebudayaan dan Perhimpunan Aksara.

Hikmat, R. H. (2017). Kebijakan Pelaksanaan Program Keluarga Harapan Tahun 2017. Disampaikan pada Diklat Family Development Session (Direktur Jenderal Perlindungan dan Jaminan SosialKementerian Sosial Republik Indonesia) pada tanggal 9 Maret 2017 di Kota Padang Provinsi Sumatera Barat.

Hill, Mi. (1993). The Policy Process: A Reader. London: Harvester Wheatsheaf.

Kementerian Keuangan. (2015). Kajian Program Keluarga Harapan. Diterbitkan oleh Direktorat Jenderal Anggaran - Kementerian Keuangan Republik Indonesia.

Kementerian Sosial. (2013). Sistem Pengaduan Masyarakat Program Keluarga Harapan (SPM-PKH). Diterbitkan oleh Direktorat Jaminan Direktorat Jenderal Perindungan dan Jaminan Sosial - Kementerian Sosial Republik Indonesia.
Kementerian Sosial. (2016). Kebijakan Pelaksanaan Program Keluarga Harapan. Direktorat Jenderal Perlindungan dan Jaminan SosialKementerian Sosial Republik Indonesia.

Makinde, T. (2005). Problems of Policy Implementation in Developing Nations: The Nigerian Experience. J. Soc. Sci. 11(1), 63-69.

Maksum, I. R. (2017). Administrasi Publik dan Kebijakan Publik. Presentasi sebagai materi ajar dalam perkuliahan program pasca sarjana Ilmu Administrasi dan Kebijakan Publik - Universitas Indonesia Semester I Tahun Ajaran 2017/2018.

Nachmias, D. (1979). Public Policy Evaluation: Approaches and Methods. New York: ST Martin's Press.

Nafatilona, N. (2011). Analisis Pelaksanaan Program Keluarga Harapan (PKH) Kota Administrasi Jakarta Utara (Studi Kasus di Kelurahan Warakas, Kecamatan Tanjung Priok). Tesis. Jurusan Perencanaan dan Kebijakan Publik - Fakultas Ekonomi - Universitas Indonesia.

Nugroho, R. (2011). Public Policy: Dinamika Kebijakan-Analisis Kebijakan-Manajemen Kebijakan. Jakarta: Elex Media Komputindo.

Patton, C. V.; Sawicki, D. S.; Clark, J. J. (2013). Basic Methods of Policy Analysis and Planning: Third Edition. New York: Pearson. 
Setyodarmodjo, S. (2005). Public Utomo, D., Abdul, H., Heru, R. (2014). Policy: Pengertian Pokok Pelaksanaan Program Keluarga Untuk Memahami dan Analisa Harapan Dalam Meningkatkan Kebijaksanaan Pemerintah. Kualitas Hidup Rumah Tangga Surabaya: Airlangga University Press.

Sugiyono. (2004). Metode Penelitian Administrasi. Bandung: Alfabeta.

Triyono, B. (2014). Pengaturan Kelembagaan (Institutional Setting) dan Koordinasi Antar Aktor Sistem Inovasi Nasional di Indonesia, dalam Tata Kelola Sistem Inovasi Nasional di Indonesia: Jakarta: LIPI Press.

Trochim, W.M.K. (2009). Evaluation policy and evaluation practice. In W.M.K. Trochim,M. M. Mark, \& Miskin (Studi pada Unit Pelaksana Program Keluarga Harapan Kecamatan Purwoasri, Kabupaten Kediri). Jurnal Administrasi Publik (JAP), 2 (1), 29-34.

Zufri, O. R. (2014). Peran Pendamping Program Keluarga Harapan (PKH) di Kabupaten Jombang (Studi Deskriptif Pada Suku Dinas Kabupaten Jombang Propinsi Jawa Timur). Skripsi. Jurusan Ilmu Kesejahteraan Sosial-Fakultas Ilmu Sosial dan Politik-Universitas Jember.

L. J. Cooksy (Eds.), Evaluation policy and evaluation practice. New Directionsfor Evaluation, 123, 13-32. 